\title{
Pemanfaatan Limbah Minyak Jelantah Penghasil Sabun Sebagai Stimulus Untuk Meningkatkan Kepedulian Masyarakat Terhadap Lingkungan
}

\author{
Arif Abdul Haqq \\ IAIN Syekh Nurjati Cirebon, \\ e-mail:mr.haqq@gmail.com
}

\begin{abstract}
ABSTRAK
Penelitian ini bertujuan untuk melihat fenomena kepedulian masyarakat terhadap lingkungan sebagai implikasi dari pemanfaatan limbah minyak jelantah yang merupakan limbah anorganik rumah tangga. Sudah barang tentu setiap rumah tangga menghasilkan minyak jelantah karena penggunaan minyak goreng merupakan salah satu kebutuhan primer masarakat. Dengan adanya perlakuan melalui pemanfaatan limbah minyak jelantah menjadi sabun, masyarakat memiliki peran penting terhadap pengendalian dari limbah tersebut. Fenomena kepedulian lingkungan masyarakat setelah diberi stimulus pemanfaatan limbah minyak jelantah dilihat melalui metode kuantitatif deskriptif. Stimulus diberikan dalam rangkaian kegiatan pos pemberdayaan pemberdayaan keluarga (POSDAYA). Data diambil melalui hasil survey dengan menggunakan alat pengumpul data berupa kuesioner literasi lingkungan, keterampilan pemanfaatan minyak jelantah menjadi sabun, perilaku kepedulian terhadap lingkungan, dan tindakan peduli lingkungan. Data tersebut diolah dengan bantuan MSI (Methods of Successive Interval) dan software SPSS untuk melihat angka koefisien korelasi Spearman. Berdasarkan hasil survey pada 76 responden yang diambil sebagai sampel, fenomena tingkat kepedulian masyarakat masyarakat Desa Windujaya Kecamatan Sedong Kabupaten Cirebon menunjukkan kecenderungan ke arah positif. Faktor yang mempengaruhi secara signifikan adalah literasi lingkungan dan keterampilan dalam memanfaatkan limbah minyak jelantah menjadi sabun.
\end{abstract}

Kata Kunci: Sampah rumah tangga, pengolahan, potensi masyarakat, pemberdayaan

\begin{abstract}
This research aims to look at the phenomenon of community awrness for the environment as the implications of the utilization of waste cooking oil which is a household inorganic waste. Of course, every household produces used waste cooking oil because cooking oil is one of the primary needs of the community. With the treatment through the utilization of waste cooking oil into soap, community has an important role in the control of the waste. The phenomenon of environmental awarness after being given the stimulus of waste cooking oil utilization was seen through descriptive quantitative methods. The stimulus is given in a series of family empowerment center activities (POSDAYA). Data was collected through survey results using data collection tools in the questionnaires form of environmental literacy, skil of utilization of waste cooking oil into soap, awarness behaviors, and actions of environtmental awareness. The data is processed with the help of MSI (Methods of Successive Interval) and SPSS software to see the Spearman correlation coefficient. Based on the results of a survey of 76 respondents taken as a sample, the phenomenon of the level of community awareness in the community of Windujaya Village, Sedong Subdistrict, Cirebon District showed a positive trend. Significantly influencing factors are environmental literacy and skills in utilizing waste cooking oil into soap.
\end{abstract}

Keywords: Household waste, processing, community potential, empowerment 


\section{PENDAHULUAN}

Dalam dekade terakhir ini, permasalahan lingkungan hidup dan laju kerusakan serta pencemaran lingkungan semakin hari semakin meningkat. Persoalan lingkungan di antaranya adalah pengelolaan limbah karena menyangkut masyarakat luas. Hal ini perlu dikelola dengan benar agar tidak dapat menimbulkan kerusakan yang serius bagi lingkungan. Masyarakat sebagai pelaku konsumsi sudah barang tentu akan menghasilkan limbahnya sendiri sebagai hasil dari kehidupan sehari-hari (Sunarsi, 2014). Keseriusan masyarakat merupakan kunci utama keberhasilan dalam pengelolaan limbah terutama sampah rumah tangga. Seperti halnya tercantum dalam PP RI No. 81 Tahun 2012 tentang pengelolaan sampah rumah tangga dan sampah sejenis sampah rumah tangga terutama pada poin f yang menyebutkkan multi peran yang dipegang masyarakat seperti decision maker, penyelenggaraan, dan pengawasan dalam kegiatan pengelolaan sampah rumah tangga (Inayah \& Suprapto, 2017). Untuk itu peningkatan kepedulian, literasi dan tindakan peduli lingkungan masyarakat merupakan hal utama dalam pengelolaan sampah rumah tangga.

Kerusakan lingkungan merupakan penurunan kualitas lingkungan sampai pada tingkat tertentu yang menyebabkan lingkungan mengalami disfungsi sesuai perannya (Wahyudin, 2017). Kerusakan pada lingkungan mengacu pada dua jenis bencana yang berimplikasi pada rusaknya daya dukung lingkungan. Kerusakan yang berasal dari alam itu sendiri dan kerusakan yang berasal dari perilaku manusianya, dalam hal ini masyarakat. Bagi masyarakat, kerusakan yang berasal dari alam ini sulit dihindari karena tidak terprediksi kapan terjadinya. Dapat berdampak dalam waktu yang singkat, atau bahkan berdampak dalam waktu yang lama. Kerusakan lingkungan yang berasal dari perilaku manusia.Terutama beralasan demi meningkatkan kualitas dan kenyamanan hidup. Kerusakan daya dukung sebagai akibat dari kegiatan-kegiatan, seperti: industrialisasi, penggunaan bahan bakar fosil dan limbah rumah tangga yang dibuang di sungai-sungai.

Salah satu sampah rumah tangga yang dapat memberikan dampak serius bagi lingkungan adalah minyak goreng bekas atau minyak jelantah. Limbah minyak jelantah berpotensi mencemari tanah dan air ketika tidak dikelola dengan benar. Minyak jelantah merupakan senyawa berupa limbah yang mengandung karsinogenik dengan bilangan asam dan peroksida yang tinggi (Erviana, Suwartini, \& Mudayana, 2018). Minyak jelantah yang dibuang sembarangan mengalir ke saluran air hingga merubah senyawa air itu sendiri menjadi tidak layak digunakan. Pun minyak jelantah yang tidak dikelola dengan benar bias meresap ke tanah dan mengganggu unsur hara yang ada di tanah. Akibatnya tanah yang harusnya bisa ditanami pohon, menjadi tidak subur lagi. Apa lagi sistem TPA di Indonesia bersifat terbuka, seringnya dibiarkan begitu saja tanpa perlakuan sesegera 
mungkin (Vanessa \& Bouta, 2017). Hal ini dapat menyebabkan peluang tercemarnya lingkungan terutama air dan tanah semakin besar.

Minyak jelantah sebenarnya bisa didaur ulang menjadi minyak goreng melalui proses penyaringan. Namun, menurut (Erviana et al., 2018) terdapat perubahan kualitas dari kandungannya yang cenderung mengalami penurunan kualitas. Berdasarkan Standar Nasional Indonesia (SNI) hasil daur ulang minyak goreng ini sebenarnya masih layak untuk dikonsumsi, hanya saja memerlukan proses adsorbs dengan cara yang tepat (Rahayu \& Purnavita, 2014). Minyak goreng yang digunakan berulang kali mengakibatkan perubahan fisik, rasa, dan aroma yang menjadi tidak sedap. Kadar keasaman mencapai 3,142 $\mathrm{mgKOH} / \mathrm{g}$ lebih besar 0,142 $\mathrm{mgKOH} / \mathrm{g}$ dari ambang batas American Oil Chemist's Society (AOCS), Kandungan asam lemak bebas mencapai $1,571 \%$ lebih besar dari ambang batasnya yang kurang dari 1\%, (Vanessa \& Bouta, 2017). Alih-alih ingin menghasilkan minyak goreng dengan harga murah melalui proses daur ulang, malah menambah resiko bagi kesehatan masyarakat.

Kepedulian masyarakat Desa Windujaya Kecamatan Sedong Kabupaten Cirebon terhadap lingkungan masih tergolong rendah. Hal ini dibuktikan dengan masih banyak warga yang membuang sampah rumah tangga di sungai sehingga sungai menjadi kotor dan tercemar sampah rumah tangga, maka diadakanlah workshop pemanfaatan limbah minyak jelantah menjadi sabun. Selain workshop, diberikan pula pemaparan informasi terkait dampak negative dari pengelolaan sampah rumah tangga yang tidak dikelola dengan benar. Hal ini sejalan dengan (Desfandi, 2015) yang menyatakan bahwa Masyarakat internasional saat ini telah menyepakati pentingnya menjaga bumi dari pencemaran dan kerusakan dengan memahami interkasi antara alam dengan masyarakat guna kelangsungan hidup yang bersifat kontinuitas. Dengan memberikan informasi mengenai pengelolaan sampah rumah tangga yang benar, masyarakat menambah kemampuan literasi lingkungan. Selain itu, masyarakat mampu mengembangkan keterampilannya dalam memanfaatkan minyak jelantah menjadi sabun melalui kegiatan workshop tersebut.

Literasi lingkungan dan keterampilan dalam memanfaatkan minyak jelantah menjadi sabun dapat menggiring perilaku kepedulian terhadap lingkungan dan tindakan peduli lingkungan kea rah yang positif. Gagasan ini sejalan dengan (Zakiyyah, Zuhud \& Sumardjo, 2016) yang menyatakan bahwa sikap dan perilaku masyarakat, serta aksinya terhadap lingkungan merupakan hasil stimulus dari pengetahuan dan keterampilan dalam mengelola lingkungan itu sendiri. Kegiatan literasi lingkungan dan keterampilan dalam memanfaatkan minyak jelantah menjadi sabun dikembangkan melalui pos pemberdayaan keluarga (POSDAYA). POSDAYA merupakan sebuah wadah atau lembaga yang berfungsi sebagai forum diskusi, silaturahmi, advokasi, komunikasi, edukasi, dan 
wadah kegiatan penguatan fungsi-fungsi keluarga secara terpadu yang dilaksanakan dari, oleh, dan untuk keluarga dan masyarakat (Zakiyyah \& Haqq, 2018).

Banyak penelitian yang membahas tentang bagaimana pengelolaan minyak jelantah menjadi sabun. Seperti pada penelitian (Sumiati et al., 2019) yang menemukan fakta bahwa proses kegiatan diversifikasi minyak jelantah dapat memberikan wawasan kepada masyarakat. (Erviana et al., 2018) menemukan fakta bahwa dengan melalui kegiatan membuat minyak jelantah menjadi sabun berbasis zero waste industry membantu masyarakat dalam memanfaatkan sampah rumah tangga. (Hajar, Auxilia, \& Putri, 2016) menemukan fakta bahwa sabun padat dapat terbuat dari minyak jelantah berupa minyak kelapa dan minyak jagung bekas. Begitu pula penelitian-penelitian lainnya tentang minyak jelantah, hampir seluruhnya membahas tentang bagaimana proses pembuatannya. Belum ada penelitian yang membahas pemanfaatan minyak jelantah yang dapat menjadi stimulus peningkatan kepedulian masyarakat terhadap lingkungan. Oleh karenanya dalam penelitian ini dibahas tentang literasi pemanfaatan minyak jelantah menjadi sabun dan tingkat kepedulian masyarakat serta tindakannya terhadap lingkungan.

\section{BAHAN DAN METODE}

Penelitian ini dilaksanakan sejak Bulan September - Oktober 2019. Wilayah penelitian berada di Kecamatan Sedong, Kabupaten Cirebon tepatnya berada di Desa Windujaya. Pemilihan lokasi secara sengaja didasarkan pada kesesuaian karakteristik masyarakat yang belum mengetahui pemanfaatan minyak jelantah menjadi sabun dan rendah dalam kepedulian lingkungan. Jenis penelitian ini adalah penelitian kuantitatif deskriptif dengan data diambil melalui hasil survey. Alat pengumpul data yang digunakan berupa kuesioner literasi lingkungan, keterampilan pemanfaatan minyak jelantah menjadi sabun, perilaku kepedulian terhadap lingkungan dan tindakan peduli lingkungan. Data tersebut diolah dengan bantuan MSI (Methods of Successive Interval) dan software SPSS untuk melihat angka koefisien korelasi Spearman.

Adapun desain penelitian ini dapat digambarkan sebagai berikut:

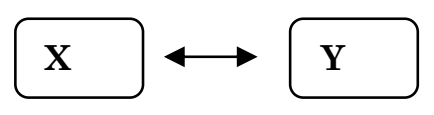

Keterangan :

$\mathrm{X}=$ Literasi lingkungan, keterampilan pemanfaatan minyak jelantah menjadi sabun

$\mathrm{Y}=$ Perilaku kepedulian terhadap lingkungan dan tindakan peduli lingkungan

$\leftrightarrow=$ Korelasi intensitas stimulus X terhadap Y

Data yang terkumpul merupakan data lapangan dan data pustaka. Adapun pengambilan dan sumber data dari kedua jenis data tersebut adalah sebagai berikut: Data lapangan yaitu melalui 
observasi langsung dengan masyarakat Desa Windujaya. Data pustaka dijadikan data suplemen dari data lapangan. Responden yang diteliti meliputi masyarakat Desa Windujaya yang ikut aktif dalam POSDAYA pada kegiatan literasi lingkungan dan keterampilan pemanfaatan minyak jelantah menjadi sabun. Responden masyarakat tersebut diambil sampel dengan menggunakan teknik pengambilan sampel non-probability sampling. Mayoritas responden adalah ibu-ibu rumah tangga yang berprofesi sebagai buruh tani.

Teknik pengambilan sampel yang digunakan dalam penelitian ini adalah "non probability sampling" dengan teknik "purposive sampling". Teknik pengambilan sampel ini hanya dengan tujuan tertentu (Siregar, 2017). Tujuan yang dimaksud yaitu sampel hanya ditujukan kepada sampel yang mengikuti kegiatan literasi lingkungan dan keterampilan pemanfaatan minyak jelantah menjadi sabun. Setiap unsur yang terdapat dalam populasi tidak memiliki kesempatan atau peluang yang sama untuk dipilih sebagai sampel, bahkan probabilitas anggota tertentu untuk terpilih tidak diketahui. Pemilihan unit sampling didasarkan pada pertimbangan atau penilaian subjektif. Jumlah responden yang terpilih yakni 25 orang responden dari 84 responden populasi yang tersebar di tiga dusun Desa Windujaya.

Jenis alat penelitian yang digunakan dalam penelitian adalah kuesioner. Kuesioner digunakan sebagai alat pengumpul data dan sebagai alat ukur ketercapaian tujuan penelitian yang dilakukan. Menurut (Sugiyono, 2013) kuesioner merupakan teknik pengumpulan data yang dilakukan dengan cara memberi seperangkat pertanyaan atau pernyataan tertulis kepada responden untuk dijawabnya. Alur proses pembuatan Instrumen kuesioner dapat dilihat pada Gambar 1. 

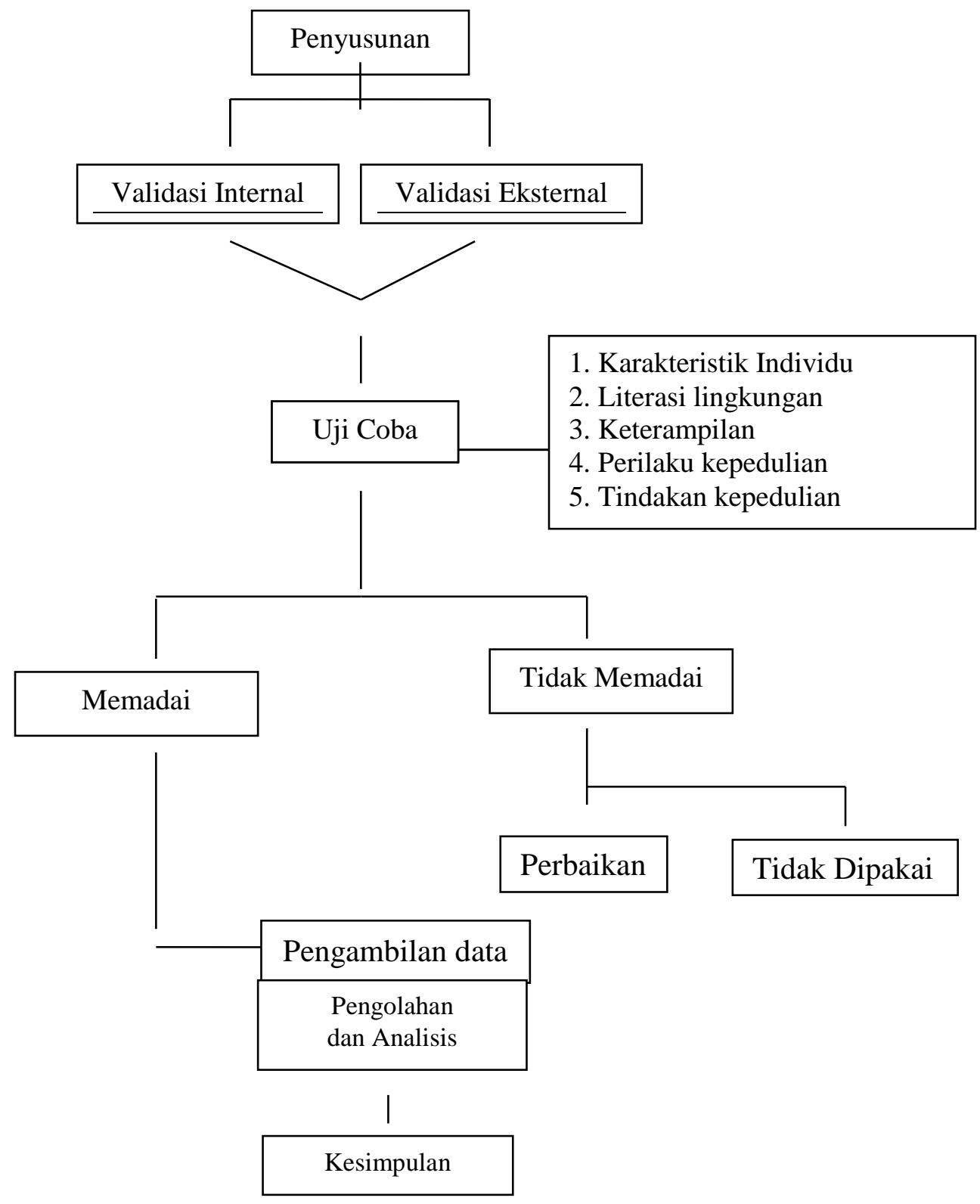

Gambar 1. Alur Proses Pembuatan Alat Pengumpul Data Kuesioner

Kuesioner yang digunakan dalam penelitian ini merupakan kuesioner yang diaplikasikan dalam Kuesioner perilaku kepedulian lingkungan masyarakat dalam pemanfaatan minyak jelantah menjadi sabun dengan menggunakan bentuk skala Likert. Butir pernyataan yang terdapat dalam kuesioner berupa bersifat negatif dan positif. Bentuk butir pernyataan responden pada kuesioner yang memiliki substansi yang bersifat negatif berupa pernyataan Sangat Tidak Setuju (STS; skor =4), Tidak Setuju (TS; skor = 3), Setuju (S; skor = 2), DAN Sangat Setuju (SS; skor = 1). Sedangkan bentuk pernyataan responden pada kuesoiner yang memiliki substansi bersifat positif berupa pernyataan Sangat Tidak Setuju (STS; skor = 1), Tidak Setuju (TS; skor = 2), Setuju (S; skor $=3$ ), dan Sangat Setuju (SS; skor $=4)$. Jumlah pernyataan pada kuesioner sikap masyarakat 
yaitu 23 pernyataan. Data yang terkumpul dari kuisioner kemudian dianalisis melalui langkahlangkah berikut:

1. Frekuensi data ordinal yang diperoleh dari hasil perhitungan kemudian ditransformasikan dalam skala interval dengan menggunakan Metode of Successive Interval (MSI), agar terdapat kesetaraan data untuk diolah lebih lanjut.

2. Data hasil perhitungan MSI kemudian dibuat dalam bentuk persentase untuk mengetahui frekuensi masing-masing alternatif jawaban yang diberikan. Untuk menentukan persentase jawaban responden, digunakan rumus berikut:

$$
\mathrm{P}=\frac{\mathrm{f}}{\mathrm{n}} \times 100 \%
$$

$$
\begin{aligned}
& \text { Keterangan: } \mathrm{P}=\text { persentase jawaban } \\
& \mathrm{f}=\text { frekuensi jawaban } \\
& \mathrm{n}=\text { banyak responden }
\end{aligned}
$$

3. Menentukan ambang stimulus dan tingkat kekuatan stimulus sikap masyarakat dengan pengkategorian sebagai berikut: Pengkategorian stimulus untuk sikap masyarakat menurut Walgito (2004) menggunakan nilai berikut :

a) $\geq 2.99=\mathrm{Suka} /$ setuju atau sangat setuju (terbentuk tingkat stimulus kuat untuk perilaku masyarakat).

b) $<2.99$ = Tidak tahu, tidak suka/setuju, sangat tidak suka/sangat tidak setuju (belum terbentuk stimulus atau tingkat stimulus lemah untuk perilaku masyarakat).

4. Menjelaskan dalam bentuk naratif deskriptif.

Untuk mengetahui hubungan antar perubahan dilakukan analisis hubungan dengan Koefisien Korelasi Spearman. Korelasi Spearman berfungsi untuk menentukan besarnya hubungan dua variabel yang berskala ordinal yang dihasilkan dari angket konservasi tumbuhan paku $(1,2,3,4)$. Angka-angka tersebut sebenarnya hanya simbol, oleh karena itu korelasi ini termasuk uji statistik non-parametrik. Besarnya korelasi adalah $0<r_{s}<1$. Korelasi positif yang artinya searah, jika variabel pertama besar, maka variabel kedua semakin besar juga. Korelasi negatif yang artinya berlawanan arah, jika variabel pertama besar, maka variabel kedua semakin mengecil. Untuk menentukan korelasi Spearman digunakan rumus sebagai berikut:

$$
r_{s}=1-\frac{6 \sum_{n=1}^{i} d_{i}^{2}}{n\left(n^{2}-1\right)}
$$


Keterangan: $r_{s}=$ koefisien korelasi Spearman

$$
\begin{aligned}
\mathrm{n} & =\text { banyaknya pasangan data } \\
d i & =\text { jumlah selisih antara peringkat bagi } \mathrm{X} \text { dan } \mathrm{Y}
\end{aligned}
$$

\section{HASIL DAN PEMBAHASAN}

\section{Analisis Tingkat Literasi Lingkungan}

Literasi atau pengetahuan adalah unsur-unsur yang mengisi akal dan alam jiwa seorang manusia yang sadar, secara nyata terkandung dalam otaknya, artinya, bahwa pengetahuan berhubungan dengan jumlah informasi yang dimiliki seseorang (Koentjaraningrat 1990). Literasi lingkungan sendiri memiliki makna jumlah informasi yang dimiliki masyarakat mengenai lingkungan. Butir dibuat dalam bentuk pernyataan yang masing-masing pernyataan dikelompokkan ke dalam empat bentuk yaitu; literasi lingkungan masyarakat mengenai masyarakat potensi minyak jelantah menjadi sabun, kegunaan, pemanfaatan, dan ciri ekonomis minyak jelantah yang dapat digunakan menjadi sabun. Distribusi persentase tingkat literasi lingkungan masyarakat Desa Windujaya dapat dilihat secara rinci pada Tabel 1.

Tabel 1. Distribusi Persentase Tingkat Literasi Lingkungan Masyarakat Terhadap pemanfaatan limbah minyak jelantah menjadi sabun

\begin{tabular}{llccc}
\hline \multicolumn{2}{c}{ Jenis Pengetahuan } & \multicolumn{3}{c}{ Tingkat Persentase Pengetahuan } \\
\cline { 2 - 4 } & Tinggi & Sedang & Rendah \\
\hline $\begin{array}{l}\text { 1. Manfaat limbah minyak jelantah sebagai } \\
\text { alternatif } \\
\quad \text { pembuat sabun }\end{array}$ & 12.0 & 84.0 & 4 \\
$\begin{array}{l}\text { 2. Kemudahan mendapatkan minyak jelantah } \\
\text { 3. Kegunaan minyak jelantah menjadi sabun }\end{array}$ & 82.0 & 14.0 & 4.0 \\
$\begin{array}{l}\text { 4. Cara memanfaatkan minyak jelantah menjadi } \\
\text { sabun }\end{array}$ & 12.0 & 82.0 & 6.0 \\
$\begin{array}{l}\text { 5. Ciri minyak jelantah yang digunakan menjadi } \\
\text { sabun }\end{array}$ & 52.0 & 0 & 34.0 \\
6 Cara memperoleh minyak jelantah & 52.0 & 6.0 & 42.0 \\
\hline
\end{tabular}

Sumber: Data Primer, 2019

Pengetahuan masyarakat mengenai potensi minyak jelantah menjadi sabun berada pada tingkat literasi tinggi artinya sebagian besar masyarakat mengetahui bahwa minyak jelantah memiliki potensi untuk diolah kembali setelah digunakan. Pada pernyataan mengenai kegunaan minyak jelantah menjadi sabun berada pada tingkat pengetahuan sedang artinya masyarakat belum 
memahami betul mengenai kegunaan dari minyak jelantah yang dapat diolah menjadi sabun, mereka mengetahui itu hanya dapat digunakan untuk menggoreng makanan dan harganya murah.

Pengetahuan masyarakat mengenai ciri ekonomi yaitu dengan melontarkan tiga pernyataan meliputi; cara memanfaatkan minyak jelantah menjadi sabun, bentuk minyak jelantah, dan cara memperoleh minyak jelantah. Masyarakat sebagian besar memiliki tingkat pengetahuan yang tinggi mengenai ciri ekonomis. Informasi mengenai ciri ekonomis yang mereka ketahui merupakan hasil dari pengalaman selama mereka menggunakan minyak jelantah. Namun tidak sedikit juga dari mereka yang belum mengetahui informasi bentuk minyak jelantah serta cara memperolehnya.

\section{Analisis Keterampilan Pemanfaatan Minyak Jelantah}

Keterampilan pemanfaatan limbah minyak jelantah menjadi sabun adalah berbagai bentuk kegiatan yang berkaitan dengan pemanfaatan teknologi terkait cara memperoleh, teknologi cara memurnikan, teknlogi mengolah menjadi sabun, kemudahan mendapatkan minyak jelantah, dan tingkat memproduksi sabun dari bahan baku minyak jelantah. Pernyataan yang diberikan kepada masyarakat sejumlah tujuh butir pernyataan. Hasil yang diperoleh berdasarkan tujuh butir pernyataan tersebut hampir semua masyarakat memiliki tingkat keterampilan yang rendah. Distribusi persentase tingkat keterampilan lebih rinci dapat dilihat pada Tabel 2.

Tabel 2. Distribusi Persentase Tingkat Keterampilan Masyarakat Terhadap Pemanfaatan Limbah Minyak Jelantah Menjadi Sabun

\begin{tabular}{|c|c|c|c|c|}
\hline \multirow[t]{2}{*}{ No } & \multirow[t]{2}{*}{ Jenis Keterampilan } & \multicolumn{3}{|c|}{$\begin{array}{l}\text { Tingkat Persentase } \\
\text { Keterampilan }\end{array}$} \\
\hline & & Tinggi & Sedang & Rendah \\
\hline 1 & Cara membuat sabun dari minyak jelantah & 4.0 & 0 & 96.0 \\
\hline 2 & Cara memperoleh minyak jelantah untuk membuat sabun & 92.0 & 0 & 8.0 \\
\hline 3 & Masyarakat membuat sabun dari minyak jelantah sendiri & 4.0 & 0 & 96.0 \\
\hline 4 & $\begin{array}{l}\text { Berhasil atau tidak dalam membuat sabun minyak jelantah } \\
\text { sendiri menjadi }\end{array}$ & 4.0 & 0 & 96.0 \\
\hline 5 & Jika membuat sabun menggunakan media atau tidak & 0 & 0 & 100 \\
\hline 6 & $\begin{array}{l}\text { Mengajarkan kepada masyarakat lain atau tidak mengenai } \\
\text { cara membuat sabun }\end{array}$ & 0 & 0 & 100 \\
\hline 7 & $\begin{array}{l}\text { Bahan media apa yang digunakan untuk membuat sabun } \\
\text { dari minyak jelantah }\end{array}$ & 24.0 & 76.0 & 0 \\
\hline
\end{tabular}

Sumber: Data Primer, 2019

Pada pernyataan terkait teknologi cara membuat dan produktivitas sabun dari minyak jelantah yakni pada butir pernyataan $1,3,4,5$, dan 6 , masyarakat memiliki tingkat keterampilan rendah. 
Terutama pada pernyataan memengenai menggunakan media ketika membuat dan mengajarkan kepada masyarakat lain mereka seluruhnya menjawab tidak melakukan kegiatan tersebut yang artinya bahwa masyarakat memiliki keterampilan yang rendah. Alasan yang dikemukan masyarakat adalah bahwa mereka tidak melakukan kegiatan tersebut karena beranggapan bahwa minyak jelantah ada dapat diperoleh di rumah masing-masing pun medianya dan mereka tidak membuat minyak jelantah sehingga mereka tidak mengajarkan kepada masyarakat lain. Namun demikian, masyarakat tergolong terampil dalam cara membuat dan mengolah minyak jelantah menjadi sabun. Mereka sangat mengetahui bahwa membuat sabun dari minyak jelantah lebih bermanfaat dan tidak beresiko bagi kesehatan. Begitu pula minyak jelantahnya diolah sangat baik untuk dijadikan sabun pada untuk souvenir

\section{Analisis Tingkat Kepedulian Lingkungan Masyarakat}

Perilaku masyarakat Desa Windujaya dipengaruhi oleh tingkat literasi mereka tentang minyak jelantah yang dapat diolah menjadi sabun hal ini sesuai dengan pernyataan (Zakiyyah et al., 2016) bahwa masyarakat akan berperilaku terhadap suatu obyek tersebut apabila pengetahuan itu disertai dengan kesiapan untuk bertindak terhadap obyek tersebut. Masyarakat Desa Windujawya memiliki perilaku mendukung terhadap kepedulian melalui pemanfaatan minyak jelantah menjadi sabun. Adapun stimulus yang membentuk perilaku masyarakat dikategorikan menjadi tiga stimulus, yaitu stimulus natural, stimulus manfaat, dan stimulus kebaikan.

Stimulus natural pemanfaatan minyak jelantah menjadi sabun merupakan bentuk pengkarakterisasian kondisi diversifikasi dari minyak jelantah yang masyarakat ketahui dan masyarakat sikapi. Karakter spesifik yang dimaksudkan yaitu berupa bentuk fisik minyak jelantah dan asal memperoleh minyak jelantah, kandungan minyak jelantah dan tingkat kejenuhan minyak jelantah. Stimulus manfaat minyak jelantah menjadi sabun dapat dideskripsikan dari beberapa peran atau manfaat terhadap lingkungan sekitarnya. Selanjutnya pernyataan-pernyataan stimulus dibangun dari nilai manfaat minyak jelantah dari peran-sosial ekonomi, alternatif bahan pembuat sabun dan nilai kandungan gizi dan kegunaan. Masyarakat secara umum belum mendukung sepenuhnya mengenai stimulus manfaat minyak jelantah menjadi sabun. Stimulus kebaikan yaitu nilai-nilai kebaikan yang terkandung dalam pemanfaatan minyak jelantah menjadi sabun. Secara sederhana alur proses perubahan dari stimulus pemanfaatan minyak jelantah menjadi sabun menjadi perilaku kepedulian lingkungan masyarakat dapat dilihat pada Gambar 2 . 


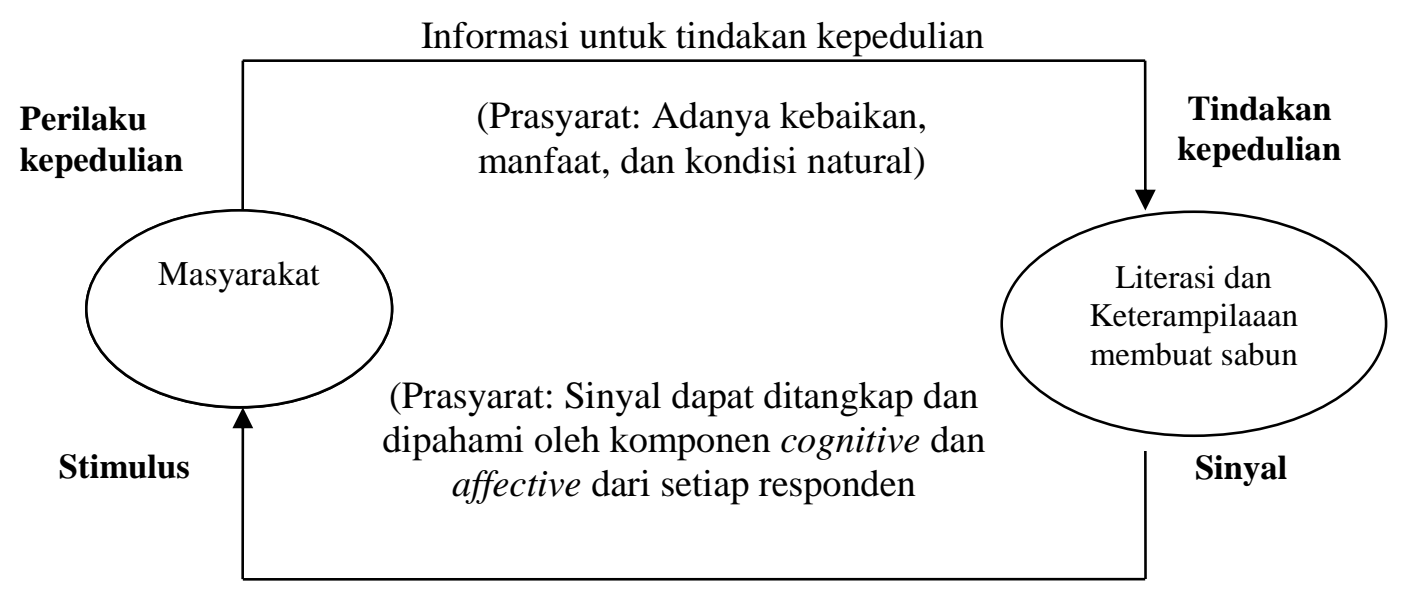

\section{Gambar 2. Alur Proses Stimulus Pemanfaatan Minyak Jelantah menjadi sabun menjadi Perilaku Kepedulian Lingkungan Masarakat}

Pernyataan pernyataan mengenai stimulus natural yang disampaikan kepada masyarakat menunjukkan hasil bahwa masyarakat Desa Windujaya menyepakati semua pernyataan pernyataan tersebut. Masyarakat mengetahui karakterisasi minyak jelantah. Sifat natural yang ada pada minyak jelantah dipahami oleh masyarakat karena mereka mengamati setiap kali menggunakannya untuk menggoreng. Keberadaan minyak jelantah yang mudah didapatkan membuat masyarakat paham karakteristik natural minyak jelantah.

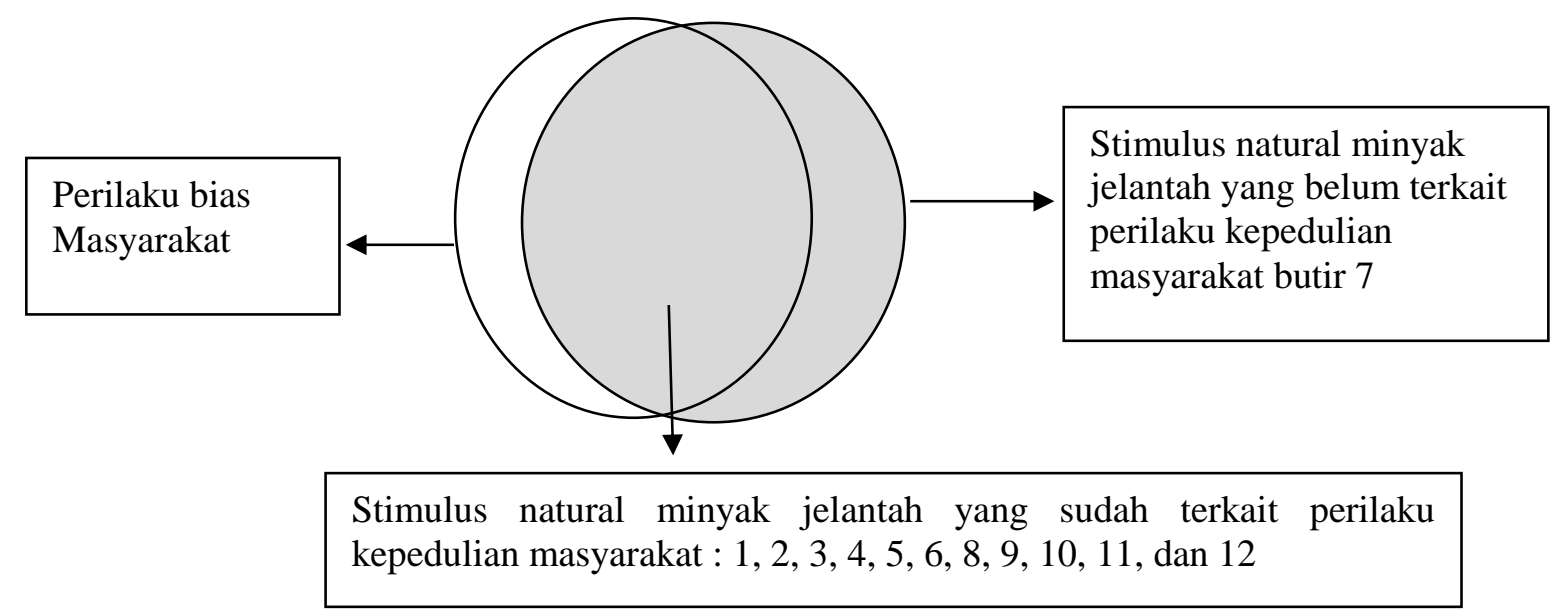

Gambar 3. Perilaku Masyarakat terhadap Stimulus Natural Minyak Jelantah

\section{Keterangan:}

\begin{tabular}{lllc}
\hline No & \multicolumn{1}{c}{ Pernyataan Stimulus Alamiah } & Skor Rataan & Perilaku \\
\hline 1 & Minyak jelantah bias didapatkan di rumah sendiri & 3.76 & + \\
2 & $\begin{array}{l}\text { Minyak jelantah dihasilkan setelah minyak goreng } \\
\text { digunakan berulang-ulang }\end{array}$ & 3.04 & + \\
\hline
\end{tabular}




\begin{tabular}{|c|c|c|c|}
\hline No & Pernyataan Stimulus Alamiah & Skor Rataan & Perilaku \\
\hline 3 & $\begin{array}{l}\text { Minyak jelantah berada pada tingkat kejenuhan yang } \\
\text { tinggi }\end{array}$ & 3 & + \\
\hline 4 & Minyak jelantah banyak didapatkan di pasar & 3.24 & + \\
\hline 5 & Minyak jelantah berasal dari limbah rumah tangga & 3.64 & + \\
\hline 6 & $\begin{array}{l}\text { Minyak jelantah berwarna lebih gelap dari minyak } \\
\text { goreng }\end{array}$ & 3.24 & + \\
\hline 7 & $\begin{array}{l}\text { Membutuhkan waktu lebih dari sekitar empat kali } \\
\text { penggunaan minyak goreng agar menjadi minyak } \\
\text { jelantah }\end{array}$ & 2.96 & - \\
\hline 8 & $\begin{array}{l}\text { Minyak jelantah memiliki warna cokelat tua setelah } \\
\text { dibuang }\end{array}$ & 3.2 & + \\
\hline 9 & $\begin{array}{l}\text { Minyak jelantah semakin gelap warnanya, maka } \\
\text { semakin jelek kualitasnya }\end{array}$ & 3.52 & + \\
\hline 10 & Minyak jelantah agak berbau tengik & 3.24 & + \\
\hline 11 & Terdapat endapan dalam minyak jelantah & 3.4 & + \\
\hline 12 & $\begin{array}{l}\text { Semakin gelap warna minyak jelantah, kandungan } \\
\text { gizinya semakin buruk }\end{array}$ & 3.68 & + \\
\hline
\end{tabular}

Sumber: Data Primer, 2019

Gambar 3 memberikan gambaran sinyal dari minyak jelantah atau stimulus natural minyak jelantah belum bisa sepenuhnya diterima menjadi perilaku oleh masyarakat. Terdapat satu pernyataan yang belum diterima oleh masyarakat yaitu mengenai waktu perubahan darai minyak goreng menjadi minyak jelantah. Masyarakat belum menerimanya karena mereka belum pernah melakukan pengamatan setelah penggunaan pengulangan minyak goreng yang ke-berapa untuk menjadi minyak jelantah.

Nilai manfaat pembentuk stimulus manfaat untuk perilaku masyarakat teridentifikasi dengan manfaat sosial-ekonomi yakni masyarakat sudah menggunakan minyak jelantah karena murah harganya, hampir semua lapisan masyarakat mengakui akan hal tersebut. Kemudian pada aspek alternatif bahan pembuat sabun dan kegunaannya masyarakat belum memahami dengan baik mereka hanya mengetahui bahwa selepas menggunakan minyak goreng yang berkali-kali baru akan menjadi minyak jelantah. Namun ketika mereka ditanyakan mengenai apakah minyak jelantah dapat dijadikan sabun pencuci lantai beberapa masyarakat yang tidak mengetahui hal tersebut. Pengetahuan nilai gizi dan kandungan minyak jelantah belum tersampaikan oleh masyarakat. (Desfandi, 2015) menerangkan bahwa untuk mengubah perilaku masyarakat perlu diwujudkan melalui pendidikan yang berkesinambungan dan terus-menerus agar informasi yang mendasar dan relevan dapat benar-benar diterima. Dalam merealisasikan hal tersebut dilakukan penyebaran informasi kepada masyarakat melalui workshop dan penyuluhan tentang manfaat 
minyak jelantah dan diversifikasinya. Diharapkan setelah melakukan penyuluhan masyarakat tidak hanya sekedar mengubahnya menjadi sabun namun masyarkat menjadikan minyak jelantah sebagai alternatif untuk mengembangkan unit usaha.

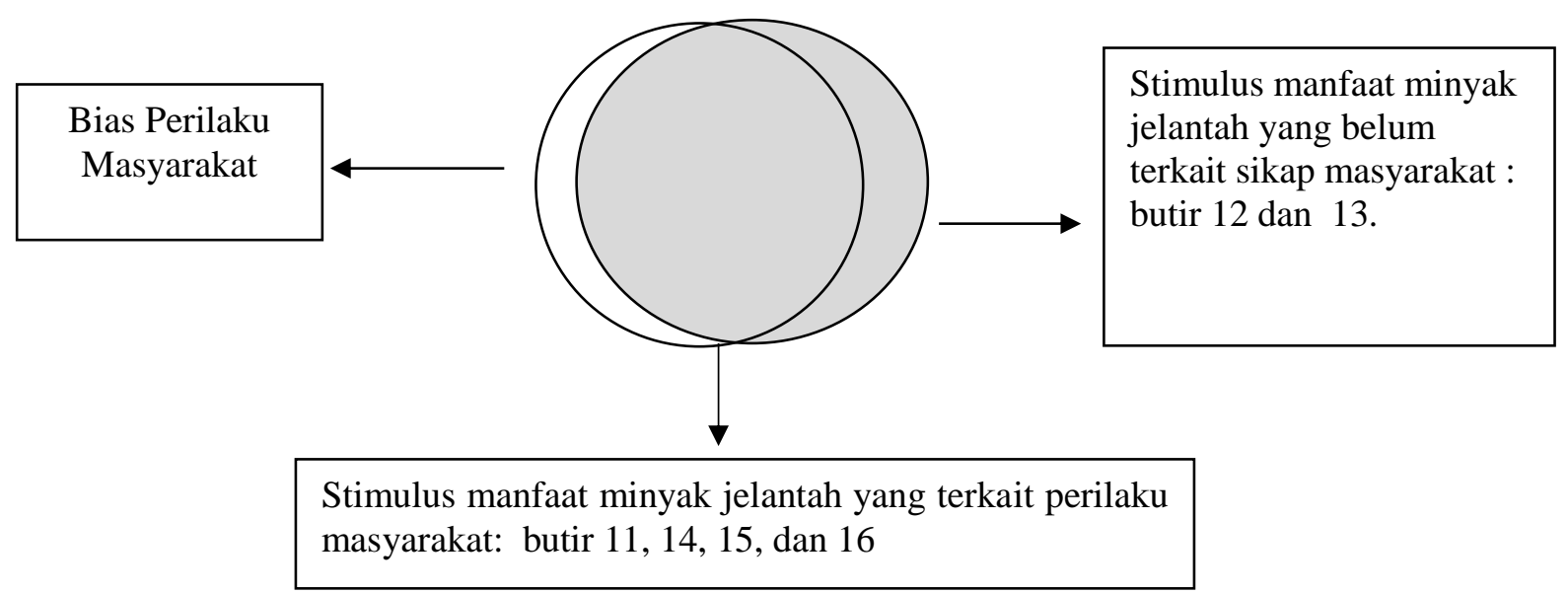

Gambar 4. Perilaku Masyarakat terhadap Stimulus Manfaat Minyak Jelantah

\section{Keterangan:}

\begin{tabular}{|c|c|c|c|}
\hline No & Pernyataan Stimulus Alamiah & Skor Rataan & Perilaku \\
\hline 11 & $\begin{array}{l}\text { Minyak jelantah dapat digunakan karena murah } \\
\text { harganya }\end{array}$ & 3.68 & + \\
\hline 12 & $\begin{array}{l}\text { Minyak jelantah dapat dijadikan sebagai bahan } \\
\text { pembuat sabun }\end{array}$ & 2.84 & - \\
\hline 13 & $\begin{array}{l}\text { Minyak jelantah dapat digunakan untuk membuat } \\
\text { sabun pencuci lantai }\end{array}$ & 2.56 & - \\
\hline 14 & $\begin{array}{l}\text { Minyak jelantah yang sudah menjadi sabun dapat } \\
\text { dijadikan alternatif untuk menghasilkan pendapatan } \\
\text { langsung }\end{array}$ & 3.44 & + \\
\hline 15 & $\begin{array}{l}\text { Menggunakan minyak jelantah membahayakan } \\
\text { kesehatan }\end{array}$ & 2.52 & - \\
\hline 16 & Minyak jelantah memiliki nilai gizi yang buruk & 2.68 & - \\
\hline
\end{tabular}

Sumber: Data Primer, 2019

Manfaat minyak jelantah bagi masyarakat bahwa minyak jelantah hanya dipahami sebagai alternatif media menggoreng yang lebih murah tanpa memperhatikan resiko kesehatan dan nilai gizinya. Masyarakat belum memahami sepenuhnya bahwa minyak jelantah dapat dilakukan diversifikasi menjadi barang yang layak pakai seperti sabun souvenir dan sabun pencuci lantai yang bahkan memiliki nilai ekonomis. 


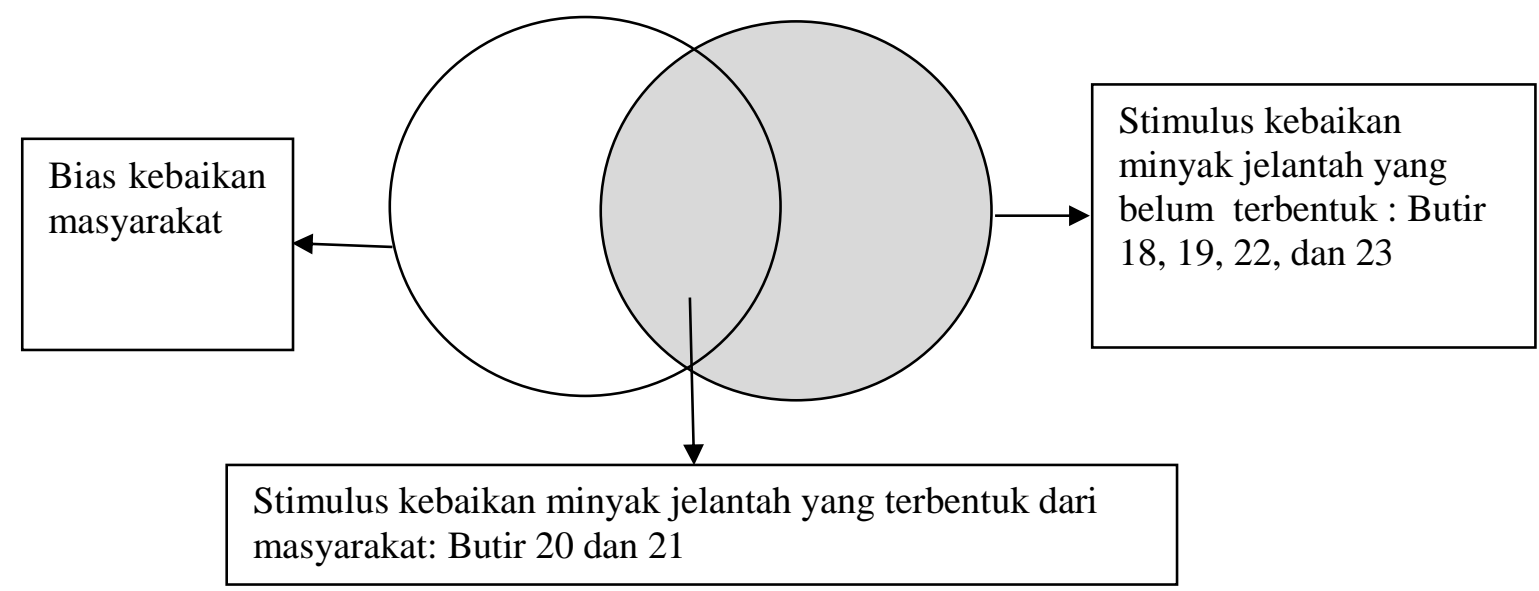

Gambar 5. Kebaikan Pemanfaatan Minyak Jelantah Menjadi Sabun Terhadap Perilaku Kepedulian Lingkungan Masyarakat

Keterangan:

\begin{tabular}{llll}
\hline No & Pernyataan Stimulus Alamiah & $\begin{array}{l}\text { Skor } \\
\text { Rataan }\end{array}$ & Sikap \\
\hline 18 & Minyak jelantah dapat dimanfaatkan menjadi sabun & 2.84 & - \\
19 & Minyak jelantah dapat didaur ulang menjadi pencuci lantai & 2.56 & - \\
20 & $\begin{array}{l}\text { Minyak jelantah dapat digunakan secara terus menerus } \\
\text { tanpa mengganggu kesehatan }\end{array}$ & +44 & + \\
21 & Minyak jelantah dapat dihasilkan di rumah sendiri & 3.52 & + \\
22 & Minyak jelantah yang dijadikan sabun lebih bermanfaat & 1.76 & - \\
23 & Sabun dari minyak jelantah efektif sebagai pembersih & 1.84 & - \\
& kotoran & & \\
\hline
\end{tabular}

Sumber: Data Primer, 2019

Berdasarkan hasil penelitian yang ditunjukkan pada Gambar 5 masyarakat belum melakukan kebaikan sepenuhnya untuk pemanfaatan minyak jelantah menjadi sabun hasil tersebut didapatkan dengan melakukan pengujian enam pernyataan mengenai kebaikan masyarakat. Dua dari enam pernyataan menjadi perilaku masyarakat terhadap pemanfaatan minyak jelantah menjadi sabun. Namun empat pernyataan lainnya belum diterima masyarakat sebagai sesuatu yang positif oleh masyarakat, yaitu pernyataan mengenai Minyak jelantah dapat dimanfaatkan menjadi sabun, minyak jelantah dapat didaur ulang menjadi pencuci lantai, minyak jelantah yang dijadikan sabun lebih bermanfaat, dan sabun dari minyak jelantah efektif sebagai pembersih kotoran. Alasan yang mereka kemukakan ialah mereka tidak paham bagaimana membuat sabun dari bahan limbah minyak jelantah.

\section{Tindakan Kepedulian Lingkungan Masyarakat}

Tindakan berkaitan dengan kemampuan fisik dan non fisik yang terbagi menjadi tiga unsur yaitu pengetahuan (kognitif), keterampilan (psikomotor), dan sikap mental (afektif). Pernyataan 
yang diberikan kepada masyarakat sejumlah 5 butir pernyataan. Hasil yang diperoleh masyarakat sudah melakukan tindakan pemanfaatan minyak jelantah menjadi sabun namun belum mencapai kondisi yang ideal salam realisasinya.

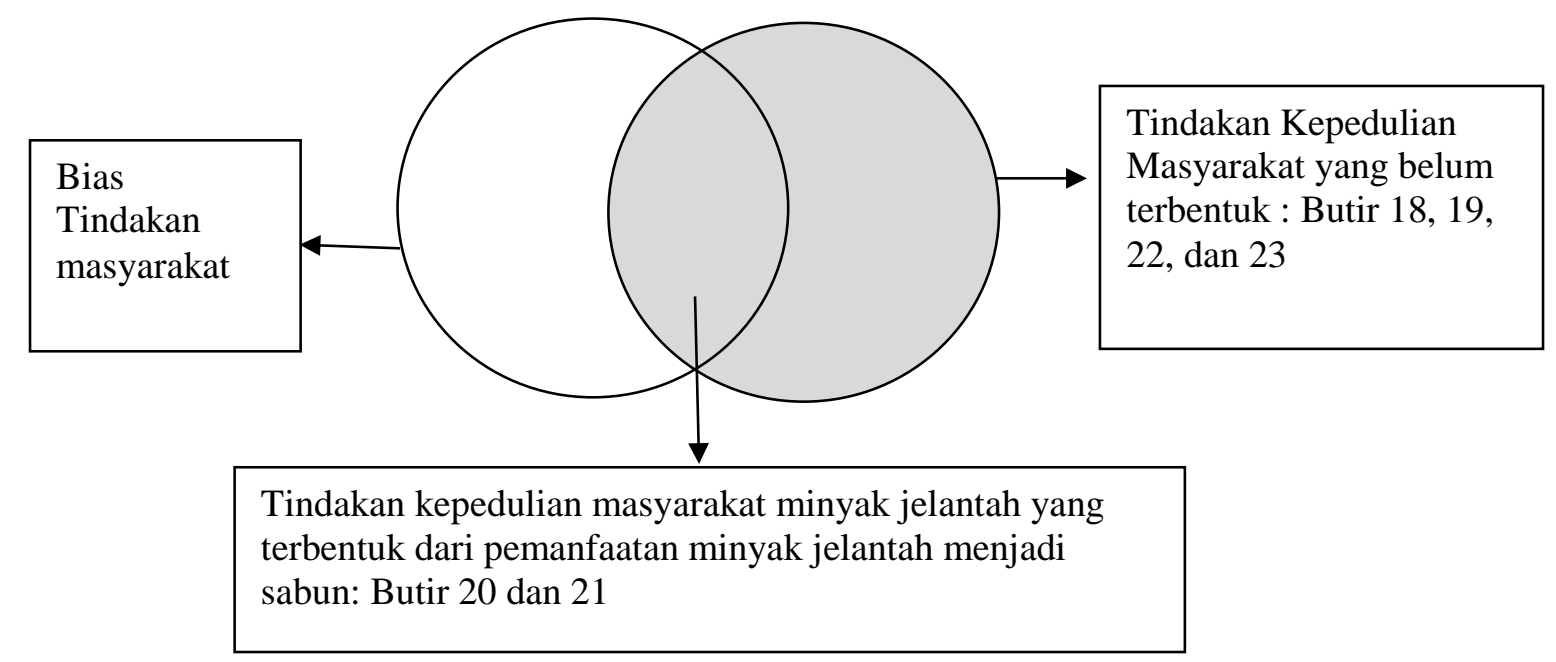

\section{Gambar 6. Kebaikan Pemanfaatan Minyak Jelantah Menjadi Sabun Terhadap Perilaku Kepedulian Lingkungan Masyarakat}

\section{Keterangan:}

\begin{tabular}{llll}
\hline No & Pernyataan Stimulus Alamiah & $\begin{array}{l}\text { Skor } \\
\text { Rataan }\end{array}$ & Sikap \\
\hline 1 & Tidak membuang minyak jelantah ke saluran air & 3.53 & + \\
2 & Mengumpulkan minyak jelantah di satu tempat khusus & 3.56 & + \\
3 & Menggunakan minyak jelantah hanya untuk membuat sabun & 2.44 & - \\
4 & Membuang minyak jelantah di pekarangan rumah & 1.76 & - \\
5 & Membuat sabun pencuci lantai sendiri dari minyak jelantah & 1.84 & - \\
\hline
\end{tabular}

\section{Sumber: Data Primer, 2019}

Tindakan kepedulian lingkungan yang sudah dilakukan masyarakat yakni tidak membuang minyak jelantah ke saluran air. Tindakan tersebut mereka lakukan karena mereka merasa akan menimbulkan bekas dan aroma yang tidak sedap ketika membuang minyak jelantah ke saluran air. Tindakan lain yang mendukung kepedulian lingkungan ialah mengumpulkan minyak jelantah di satu tempat khusus. Tindakan tersebut mereka lakukan karena memang kebiasaannya seperti demikian. Setelah tempat tersedia penuh, barulah mereka buang minyaknya.

Tindakan yang belum terwujud antara lain menggunakan minyak jelantah hanya untuk membuat sabun dan pencuci lantai. Mereka merasa kesulitan ketika kegiatannya tidak dilakukan secara bersama-sama. Tindakan lain yang belum terwujud yaitu membuang minyak jelantah di pekarangan rumah. Mereka masih beranggapan bahwa membuangnya dengan cara mengubur minyak jelantah di pekarangan rumah tidak akan menimbulkan masalah. 


\section{Perilaku Kepedulian Lingkungan Masyarakat terhadap Tindakan Kepedulian Lingkugan}

Tindakan kepedulian merupakan bentuk dari sebuh tindakan masyarakat yang menjaga betul agar lingkungan tetap pada peran dan fungsinya agar bias dirasakan terus-menerus. Tindakan kepedulian lingkunan masyarakat Desa Windujaya terhadap pemanfaatan limbah minyak jelantah menjadi sabun menghasilkan hubungan yang signifikan. Hasil tersebut dapat dilihat pada Tabel 7 .

\section{Tabel 7. Hubungan Perilaku Kepedulian Lingkungan Masyarakat terhadap Tindakan Kepedulian Lingkungan}

\begin{tabular}{lll}
\hline Variabel & Jenis Variabel & Aksi Masyarakat \\
\hline Variabel & Stimulus Natural & $0.628^{* *}$ \\
& Stimulus Manfaat & $0.432^{*}$ \\
& Stimulus Kebaikan & 0.177 \\
\hline
\end{tabular}

Sumber: Data Primer, 2019

Perilaku yang dibangun dari stimulus alamiah mempengaruhi untuk melakukan tindakan kepedulian lingkungan karena sifat atau karakter minyak jelantah sudah dimengerti dan dipahami oleh masyarakat Desa Windujaya, begitu juga dengan stimulus manfaat terdapat hubungan bahwa manfaat yang dihasilkan dari minyak jelantah mampu mebentuk tindakan kepedulian masyarakat terhadap lingkungan. Namun pada stimulus kebaikan terdapat hubungan yang lemah antara perilaku kepedulian lingkungan dengan tindakan lingkungan. Artinya kebaikan dari minyak jelantah belum dipahami benar informasinya oleh masyarakat Desa Windujaya

\section{KESIMPULAN DAN SARAN}

Perilaku kepedulian lingkungan masyarakat Desa Windujaya melalui stimulus pemanfaatan minyak jelantah menjadi sabun belum direalisasikan sepenuhnya menjadi tindakan kepedulian masyarakat terhadap lingkungan. Stimulus natural yang terdapat pada minyak jelantah bisa dimengerti oleh masyarakat hanya ada satu pernyataan yang belum disikapi begitu juga dengan stimulus manfaat, masyarakat menyikapi stimulus manfaat dengan positif namun pada stimulus kebaikan mayarakat belum menyikapi dengan sempurna. Namun fenomena tingkat kepedulian masyarakat masyarakat Desa Windujaya Kecamatan Sedong Kabupaten Cirebon secara keseluruhan sudah menunjukkan kecenderungan ke arah positif. Hal tersebut terjadi karena faktor lain yang mempengaruhi yang belum terpapar dalam penelitian ini. Untuk itu penelitian selanjutnya agar mencari factor-faktor lain yang dapat mempengaruhi perilaku kepedulian lingkungan melalui stimulus pemanfaatan sampah rumah tangga. 


\section{UCAPAN TERIMA KASIH}

Kami mengucapkan banyak terimakasih kepada Tim Lolipop yang diketuai oleh Rizki Bayu Pratama yang sudah membantu dalam kegiatan survey dan Kepala Desa Windujaya, Suwanta yang telah berkontribusi mengizinkan sekaligus memberikan informasi yang dibutuhkan penulis dalam menyelesaikan penelitian ini serta kepada Ibu Zakiyyah, M.Si Dosen pembimbing Lapangan Universitas Muhammadiyah Cirebon yang telah bersedia membantu menyelesaikan validasi instrument dalam penelitian ini.

\section{DAFTAR PUSTAKA}

Desfandi, M. (2015). Mewujudkan Masyarakat Berkarakter Peduli Lingkungan Melalui Program Adiwiyata. SOSIO DIDAKTIKA: Social Science Education Journal, 2(1), 31-37. https://doi.org/https://doi.org/10.15408/sd.v2i1.1661

Erviana, V. Y., Suwartini, I., \& Mudayana, A. (2018). Pengolahan Limbah Minyak Jelantah dan Kulit Pisang Menjadi Sabun. Jurnal SOLMA. Retrieved from https://doi.org/10.29405/solma.v7i2.2003

Hajar, E. W. I., Auxilia, F. W. P., \& Putri, H. (2016). Proses Pemurnian Minyak Jelantah Menggunakan Ampas Tebu Untuk Pembuatan Sabun Padat. Integrasi Proses, 57-63. https://doi.org/https://doi.org/http://dx.doi.org/10.36055/jip.v6i2.803

Inayah, N., \& Suprapto, R. (2017). Pendidikan Karakter melalui Pembentukan Bank Sampah Berbasis Pesantren di PP Ibnu Sina Genteng Banyuwangi. Engagement : Jurnal Pengabdian Kepada Masyarakat, 1(1), 14-27.

https://doi.org/https://doi.org/10.29062/engagement.v1i1.4

Rahayu, L. H., \& Purnavita, S. (2014). Pengaruh Suhu dan Waktu Adsorpsi terhadap Sifat Kimia-Fisika Minyak Goreng Bekas Hasil Pemurnian Menggunakan Adsorben Ampas Pati Areb dan Bentonit. Jurnal Momentum, 10(2), 35-41.

https://doi.org/https://doi.org/http://dx.doi.org/10.36499/jim.v10i2.1058

Siregar, S. (2017). Metode Penelitian Kuanti-tatif Dilengkapi Dengan Per-bandingan Hitungan Manual \& SPSS. Jakarta: Kencana Prenada Media Group.

Sugiyono. (2013). Metodologi Penelitian Kuantitatif, Kualitatif, $R \& D$. Bandung: Alfabeta. Sumiati, S., Munandar, T. A., Febriasari, A., Suryaman, S., Sulasno, S., \& Dwijayanti, A. (2019). Pemberdayaan Kelompok Ibu Rumah Tangga Melalui Pembentukan Home Industry Sabun Pencuci Lantai Berbahan Dasar Limbah Minyak Jelantah. Jurnal Al-Khidmat. 
https://doi.org/https://doi.org/10.15575/jak.v2i1.5004

Vanessa, M. C., \& Bouta, J. M. F. (2017). Analisis Jumlah Minyak Jelantah yang dihasilkan Masyarakat di Wilayah JABODETABEK. Retrieved from https://www.researchgate.net/publication/312755248

Wahyudin, U. (2017). Strategi Komunikasi Lingkungan Dalam Membangun Kepedulian Masyarakat Terhadap Lingkungan. Jurnal Common. https://doi.org/https://doi.org/10.34010/common.v1i2.576

Zakiyyah, Zuhud, E., \& Sumardjo, S. (2016). Sikap Masyarakat dan Konservasi Kasus Stimulus Bakis Community's Attitudes and Conservation A Case Stimulus of Vegetable Fern in Desa Gunung. Jurnal Pengelolaan Sumberdaya Alam Dan Lingkungan, 7(1), 71-76. https://doi.org/https://doi.org/10.19081/jpsl.6.1.71

Zakiyyah, Z., \& Haqq, A. A. (2018). Strategi Dakwah Bil Hal Dalam Program Posdaya Berbasis Masjid. ORASI: Jurnal Dakwah Dan Komunikasi. https://doi.org/https://doi.org/10.24235/orasi.v9i1.2969 